Медіафорум : аналітика, прогнози, інформаційний менеджмент : 3б. наук. праць. - Чернівці :

Чернівецький нац. ун-т, 2020. -

Том 8. - C. 202-208
Mediarorum: Analytics, Forecasts, Information Management: Collection of Research Articles. - Chernivtsi: Chernivtsi National University, 2020. Vol. 8. - pp. 202-208

https://doi.org/10.31861/mediaforum.2020.8.202-208

УДК: 323.3 (325.14)

(C) Євгенія Блажевська

\title{
MAKING OF REFUGEE POLICY IN UK IN THE EARLY 2000'S
}

This article provides a comprehensive overview of Britain's immigration policy early 2000's. Britain was once known as a country of 'zero immigration' and given that the majority of Britain's post-war restrictive measures were targeted at non-white immigrants, many scholars contend that Britain's immigration regime was underpinned by a racialized discourse. In stark contrast to Britain's past record, the Labour governments of 1997 to 2010 pursued an expansionary economic immigration policy. The chapter builds a narrative of British immigration policy until 2010 and serves to demonstrate the unprecedented shift under the Labour governments in comparison to Britain's post-war restrictive framing.

Key words: Great Britain, European Union, immigration, high-skilled migrants, the points system.

\section{Формування політики Великої Британії щодо біженців на початку 2000-х років}

Узапропонованій статті подано огляд імміграційної політики Великої Британії у першій декаді 2000-х. Стаття аналізує імміграційну політику Великої Британії щобо біженців. Упродовж тривалого часу Британія була відома як країна „нульової імміграції” та враховуючи, що більшість повоєнних обмежувальних заходів у Великій Британії були спрямовані на іммігрантів, які були расово відмінними від корінних жителів Британських островів. Расистський дискурс імміграційної політики Великої Британії визначав форми та методи ії реалізації. На відміну від минулих запитів Великої Британії, лейбористські уряди 1997-2010 років проводили експансивну економічну імміграційну політику.

1 Аспірантка кафедри міжнародних відносин факультету історії, політології та міжнародних відносин Чернівецького національного університету імені Юрія Федьковича. E-mail: via_de_feliz@ukr.net 
У статті аналізується імміграційна політика Великої Британії як демонстрація безпрецедентної трансбормачї політики уряду лейбористів порівняно з повоєнними рестрикційними заходами.

Ключові слова: Велика Британія, Європейський Союз, імміграчія, висококвалібіковані мігранти, бальна система.

Though Britain had a reputation of zero immigration and has been reluctant to join the Schegen Agreement, thus preserving its sovereignty over immigration, it was rather bold in its position regarding the access of EU nationals of its labour market. The United Kingdom was one of three countries - including Ireland and Sweden - to grant full rights to work to citizens from Czech Republic, Estonia, Hungary, Latvia, Lithuania, Poland, Slovakia, and Slovenia. The lower level of economic developement in these central and eastern European countries was a concern for older EU member states, who saw their unrestricted movement as a threat to their labor markets, which would have been inundated (based on the perceptions of EU 15 countries) by low-wage workers from the new member states. Thus a transition period of seven years was implemented, which mediated the flow of potential migrants by delaying their access to the markets of EU 15 states in three phases. The United Kingdom, however, opted to grant immediate access, contrary to the general trend among its peers.

Besides international organizations, which are conduits for information or even peer pressure, British policymakers conducted research to assess the merits of a variety of policy options. Much of the research on alternative policies was conducted through reports the government commissioned to evaluate the domestic situation and other governments' experiences with immigration policies. Since the time of the initial change in the government's stance on economic migration in 2000, officials began looking for examples from other states. The report was important for the government's framing of the immigration debate in 2001.

Under the British system of government, the institutional structure is such that executive and the legislature virtually are one in the same. There are also very few points of access to the policymaking process, hence less opportunities for opposition groups to block legislation the government favours. In addition, there is strong party discipline, whereby members of parliament support the initiatives of the government. This is in contrast to the American system, which although the Democrats or Republicans hold a majority in either house, it is not guaranteed that party members will 
vote according to party lines (Raustiala, K.,1997). Moreover, the immigration minister Liam Byrne was quite involved in the creation of the policy and was enthusiastic about it. He was active in selling the policy to the public and Parliament. Cross-party support for the initiative was achieved. The Conservatives, the opposition at the time, were in agreement with the overarching goals of the policy, to facilitate the entry of economic migrants that will benefit the economy. Their concerns were (and still are) about the numbers. In a document laying out the position of the Tories on immigration policy, the party advocated two principles that are comparable to Labour's take on the matter. First, they propose a separation in policy and debate between asylum and economic migration. Second, crafting policy to maximize the economic benefit of some types of immigration to the United Kingdom is a strategy they would pursue.

Over a period of five months in 2005, the government consulted with various stakeholders from the trade unions to employers to immigration lawyers on the benefits of economic migration and the designing of the 204 points- based system. Nonetheless, in the United Kingdom, plans (legis-

- lation) to facilitate skilled economic migrants and students were expanding. Spencer (Spencer, S., 2003, P.351) comments that "published within months of the events of 11 September 2001, and in the midst of constant media pressure on asylum, it was already clear that control measures would dominate debate. Reform of labor migration did not, however, require primary legislation, enabling controls to be relaxed under the radar of media interest."

A critical stakeholder is the public. Liam Byrne, immigration minister at the time of the PBS in 2005, duly recognized the dilemma of satisfying the exigencies of the economy and public discontent with immigration.

He remarked, "The political risk for any government is that if you fail to solve this paradox you could lose your job ... Worse still, if we fail to solve the paradox we fail to find consent for policies vital to our future wealth and health" (Byrne, L., 2007).

The point was exemplified during the 2001 electoral season. Although Labour envisioned radically reforming the immigration system, their manifesto made no explicit mention of encouraging economic migration. Rather, there were equivocal references regarding recruiting tens of thousands of doctors, nurses, and teachers and a commitment to continue to attract the best scientists to Britain, while promoting strong-fist policies with respect to asylum. Boosting the economy's productivity and competi- 
tiveness was proposed to be achieved by upskilling the native workforce. Similarly, the Conservatives kept silent on immigration but, like Labour, emphasized cracking down on fraudulent asylum seekers and fixing the current system of its inefficiency and mismanagement (Somerville, W., 2007).

Under New Labour, as noted earlier, while public discontent, fueled by the media, continued to rage with respect to illegal immigration and asylum seekers, the government promoted the socioeconomic benefits of economic migration. New Labour even implemented one of the most liberal immigration policies Britain ever had that was meant to attract highly skilled migrant labor in 2002 and this liberal perspective was reiterated in 2008 in the midst of EU expansion to the A8 countries. The needs of employers to fill labor shortages were heeded but also structured in such a way as to demonstrate to the public the government was in control and decides who is best for the economy and society. The points system removed a degree of control from employers (no longer solely employer led) and placed it in the hands of the government.

In light of the efforts by the government to find a suitable policy, the following is an analysis of the consistency of each explanatory framework of diffusion with the sequence of events described above.

The decision rules to distinguish among and identify each theory of diffusion. Briefly, if competition is the mechanism driving diffusion, I expect the British to adopt the policy of their competitor once they realize that the latter's adoption of the points system diminishes their attractiveness to skilled international migrants. If learning, on the other hand, underlies the diffusion of the points system, I expect a domestic policy crisis to trigger a purposeful international search for successful policy alternatives. Last, if emulation is driving the policy transition of the points system, the government's reputational concerns about not meeting a standard among its peers of managing immigration should motivate adoption. The evidence suggests that learning is the mechanism underlying the spread of the points system for a few reasons.

First, motivation for adoption was inconsistent with the competition hypothesis. The decision to adopt did not stem from external sources or motivated by a change in payoffs by another country adopting the policy to attract high- skilled migrants, which rules out the competition hypothesis. The British experienced skills shortages in many important sectors including health, finance, and information technology, which have impli- 
cations for the competitiveness for their economy. In response, the government used immigration in conjunction with a domestic upskilling strategy to remedy this economic challenge. Having an immigration system that makes the United Kingdom attractive to foreign labor and facilitates the admission of skilled migrants to fill these gaps is therefore important for the productivity of the economy.

Filling skills gaps becomes more difficult, however, when other high income, post industrialized (knowledge economy) states are engaging in efforts to attract the same small pool of international migrants. The government, however, attempted to address this concern in 1991 and again in 2000 by making improvements to the existing work permit system to make it easier and quicker for employers to bring in international labor. "A major consequence of these changes was that the turnaround time for applications became a matter of days rather than weeks, thus giving the UK a competitive edge over other countries in this regard" (Clarke, J. and Salt, J., 2003, P.565). Yet, despite this "competitive edge" achieved in 2000, 206 the work- permit system was insufficient to mollify public discontent in

- the government's control of immigration; the government looked for an alternative.

Additionally, Britain's competitors - that is, the states with which it sees itself in direct competition for skilled migrants - are North America (Canada, the United States), Australasia (Australia), and Europe (Germany). These countries (except Germany) far outstrip it in their intake of international migrants, have a long history of welcoming immigrants and managing immigration, and either do not have a points system or have adopted said system many years before the United Kingdom. Canada established the points system in 1967, and Australia adopted the policy in 1979. Germany considered the policy during a similar period as the British, but the policy was not adopted. Competition theories suggest temporal clustering, to the extent that adoption occurs in proximity to that of the competitor. Obviously, there is a great lapse in time between when Canada and Australia and the United Kingdom adopted the policy, contrary to what is expected by competition theories.

Last, though the government relaxed controls to facilitate the entry of high- skilled migrants, the evidence does not suggest the government felt pressured to adopt the points system because another state had done so and that action was diminishing the United Kingdom's prospects to attract international talent. Accordingly, the points system was to establish a new 
framework to assess applicants, rather than mindless bandwagoning - that is, allowing in only those immigrants that will benefit the United Kingdom and to restore public confidence in the government.

With respect to emulation, adoption was meant to satisfy functional needs - to address their migration paradox instead of merely in an attempt to receive reputational payoffs. Indeed, the United Kingdom adopted the policy of the countries for which it has familial affinities. The United Kingdom belongs to the Anglophone family because of its colonial history with these states. Notice, however, within the same family, there are a variety of policies - particularly a difference in policy approaches among the main members of the family with regard to immigration: the United States, Canada, and Australia. The latter two have points systems, while the former does not and receives the largest absolute number of international migrants. The United States has an employer- led system. Thus, within its own family, the United Kingdom had at least two options. Why choose one over the other? The emulation explanation is too simplistic to answer this question and does not encompass the rational process for choosing a policy.

Within the context of the European Union, a case might be made that the United Kingdom was concerned with reaching the standards of their European counterparts. Although the change in the tone of the immigration debate in the United Kingdom came around the time when talks began in the EU to manage immigration for economic purposes. So though Britain may have been influenced by the trend toward reframing immigration by their peers, it was not so influenced with respect to policy approach.

What then is driving the diffusion of the points system? Evidence suggests that learning underlies this policy transition. In the United Kingdom, the policy search stemmed from the desire to better manage immigration to restore public confidence about the government's ability to control immigration and to give economic migrants a route for entry, thereby limiting abuse of the asylum system but, at the same time, balancing this against the welfare of the economy by facilitating the entry of skilled migrants. Put differently, the United Kingdom's motivation for the international search was to find a better and more efficient solution to their problem. The points system was seen as that policy that is "successful" in accomplishing this.

Conclusion. The United Kingdom engaged in a rational process or, as referred to in this study, purposeful searches to find an appropriate so- 
lution to its immigration dilemma. The point system was adopted with consideration of its appropriateness for solving Britain's policy crisis. As a manifestation of this, the government commissioned a number of reports and consultations to evaluate not only the situation at home but also alternatives practiced by other states. By doing so, the British demonstrated that they were unconcerned with adopting the policy for reputational gains but interested in assessing the experiences of other states to determine the costs and benefits of their policies. That the British examined the policies of Anglophone countries is arguably an example of channeled learning wherein potential adopters look to other governments within their social networks for examples of successful policies. In the United Kingdom, there is a repackaging of the public's concern: it's not that the public wants zero migration; rather they want managed migration. The authorities frame the public's fear in terms of their concern for abuse of the system, a clever strategy that shifts the public's attention from numbers to an issue of management. To confront and dispel this public notion, officials chose a 208 system that allows for transparency into the type of immigrants selected and the needs they fulfill.

\section{References:}

1. Byrne, L. (2007) 'Business Isn't the Only Voice'- Key Immigration Reforms Over the Last 12 Months, speech 4 June 2007, KPMG London, UK : http://tna.europarchive.org/2006110-1012820/http://press.homeoffice.gov.uk/Speeche-s/sp-lb-kmpg040-607

2. Clarke, J. and Salt, J. (2003). 'Work permits and foreign labour in the UK: a statistical review' in Labour Market Trends, November 2003, vol. 111, No. 11, London: Office for National Statistics. P. 563-574.

3. Freeman Modes of immigration politics in liberal democratic states // Winter 1995; 29(4):881-913.

4. Raustiala, K.(1997). States, NGOs, and international environmental institutions International Studies Quarterly 41 (4), P. 719-740.

5. Spencer, S. (2003) The Politics of Migration: Managing Opportunity, Conflict and Change. London: Black-well.

6. Somerville, W. (2007). Immigration under New Labour. Bristol: Policy Press, $351 \mathrm{p}$. 